\title{
SEASONAL CHAETOGNATH ABUNDANCE AND DISTRIBUTION IN A TROPICAL ESTUARY (SOUTHEASTERN, BRAZIL).
}

\author{
Luiz Loureiro Fernandes ${ }^{(1)}$; José Mauro Sterza ${ }^{(2)}$; Keyla de Oliveira Neves ${ }^{(1)}$ \\ ${ }^{1}$ Universidade Federal do Espírito Santo \\ Departamento de Ecologia e Recursos Naturais \\ (Av. Fernando Ferrari 514, 29075-910, Vitória, ES, Brasil) \\ loureiro@npd.ufes.br \\ ${ }^{2}$ Universidade Estadual do Norte Fluminense \\ Laboratório de Ciências Ambientais \\ (Av. Alberto Lamego, 2000, 28013-602, Campos, RJ, Brasil)
}

\begin{abstract}
A B S T R A C T
This study focuses on the seasonal variation of the chaetognath species in the Vitória Bay/Passage Channel estuarine system, Espírito Santo, Brazil, in terms of their abundance and distribution. Specimens of chaetognaths were collected between July 1997 and April 1998 at 10 sampling stations, with a cylindrical-conical plankton net of $200 \mu \mathrm{m}$ mesh and $30 \mathrm{~cm}$ mouth, fitted with a mechanical flowmeter. Five chaetognath species were identified: Sagitta enflata, Sagitta decipiens, Sagitta hispida, Sagitta friderici and Sagitta minima. Most of them were distributed in areas of high salinity (e.g. at the stations closest to the outer estuary). The dominant species, $S$. enflata and $S$. friderici, were more frequent in the outer estuary where salinities varied from 32 (wet season - summer) to 28 (dry season - winter). S. friderici was the only species found right in the middle of the Passage Channel, at a station close to the main freshwater input into the estuary. Results showed that chaetognaths only enter the estuary due to the tidal effect, and that they are not typical residents of this system. This is to be expected because the group normally inhabits only truly marine regions.
\end{abstract}

\section{RESUMO}

Este estudo abordou a abundância e distribuição sazonal das espécies de quetognatos, no sistema estuarino baía de Vitória/Canal da Passagem, Espírito Santo, Brasil. Os organismos foram coletados entre julho de 1997 e abril de 1998 em 10 estações amostrais, utilizando uma rede de plâncton cilíndrico-cônica de $200 \mu \mathrm{m}$ de malha e $30 \mathrm{~cm}$ de abertura de boca, dotada de um fluxômetro mecânico. Cinco espécies de quetognatos foram identificadas: Sagitta enflata, Sagitta decipiens, Sagitta hispida, Sagitta friderici e Sagitta minima. A maioria destas espécies esteve distribuída em áreas com alta salinidade (e.g. estações próximas a saída do estuário). As espécies dominantes $S$. enflata e $S$. friderici foram mais freqüentes na parte externa do estuário onde as salinidades variaram de 32 (verão - estação chuvosa) a 28 (inverno - estação seca). $S$. friderici foi a única espécie encontrada no meio do Canal da Passagem, em uma estação próxima a uma fonte de água doce para o estuário. Os resultados mostram que os quetognatos entram no estuário devido ao efeito da maré, não sendo residentes típicos desse sistema. Isto é esperado visto que este grupo normalmente habita regiões verdadeiramente marinhas.

Descriptors: Sagitta, Chaetognatha, Seasonality, Abundance, Distribution, Estuary, Brazil.

Descritores: Sagitta, Chaetognatha, Sazonalidade, Abundância, Distribuição, Estuário, Brasil.

\section{INTRODUCTION}

Chaetognaths play an important role in marine food webs, being active predators. Their diet includes a variety of pelagic organisms, consisting mainly of copepods, but they may also prey on fish larvae thus impacting the zooplankton and ictioplankton communities (Casanova, 1999). 
These organisms live in various marine habitats from polar to tropical waters and at al depths. Thirty-nine species have so far been reported in the South Atlantic between 0 and $60^{\circ} \mathrm{S}$ (Casanova, 1999). These species belong to both oceanic and coastal environments, but a few have also been found in estuarine regions. Some chaetognaths are well known as indicators of certain water masses due to their close relationship with the environmental variables (Casanova, 1999); their occurrence and distribution being determined by hydrological conditions (Liang \& Vega-Pérez, 1994).

Studies on chaetognaths in southeastern Brazil have concentrated on coastal and oceanic waters where these organisms are abundant (Almeida Prado, 1968; Vega-Pérez \& Liang, 1992; Liang \& Vega-Pérez, 1995; Liang \& Vega-Pérez, 2001; Liang \& Vega-Pérez, 2002). However, chaetognaths can also be found in Brazilian estuaries, as reported by Lansac Tôha \& Lima (1993) in the estuary of the Una do Prelado river, by Lira \& Magalhães (1996) in the Mandaú/Manguaba system in Alagoas, by Lopes (1996) in the estuaries of the Juréia-Itatins ecological station, by Montú (1980) in the Patos Lagoon estuary in Rio Grande and by Paranaguá \& Nascimento-Vieira (1984) in the Botafogo river estuary.

The main purpose of this paper was to study chaetognath distribution and abundance in the Vitória Bay/Passage Channel estuarine system, a tropical estuary in Southeastern Brazil, during an annual seasonal cycle.

\section{Material and Methods}

Study Area

The Vitória Bay/Passage Channel estuarine system $\left(20^{\circ} 23^{\prime} \mathrm{S}-40^{\circ} 20^{\prime} \mathrm{W}\right)$ is located in the Vitória metropolitan area, Espírito Santo, Brazil. With a mangrove area of 2,051 hectares and an extension of approximately 25 kilometers, this system has a horseshoe shape with two coastal water entrances, one in the Vitória Bay and the other in the Passage Channel (Fig. 1). Local depths vary from 1.5 to 10 meters (outside the main port channel), tidal currents entering the estuary by both entrances. The system is influenced by coastal waters from the Espírito Santo Bay and several rivers that flow into this system (e.g. Aribiri, Marinho, Bubu and Santa Maria rivers - this latter being the main freshwater input). The Passage Channel serves also for drainage as it is narrow and shallow, but the main tidal flow enters the system through the Vitória Bay. Average monthly temperatures range from 21 to $28^{\circ} \mathrm{C}$ and precipitation from 50 to $200 \mathrm{~mm}$, with the months of December/January being the warmest and wettest and July/August the coldest and dryest.

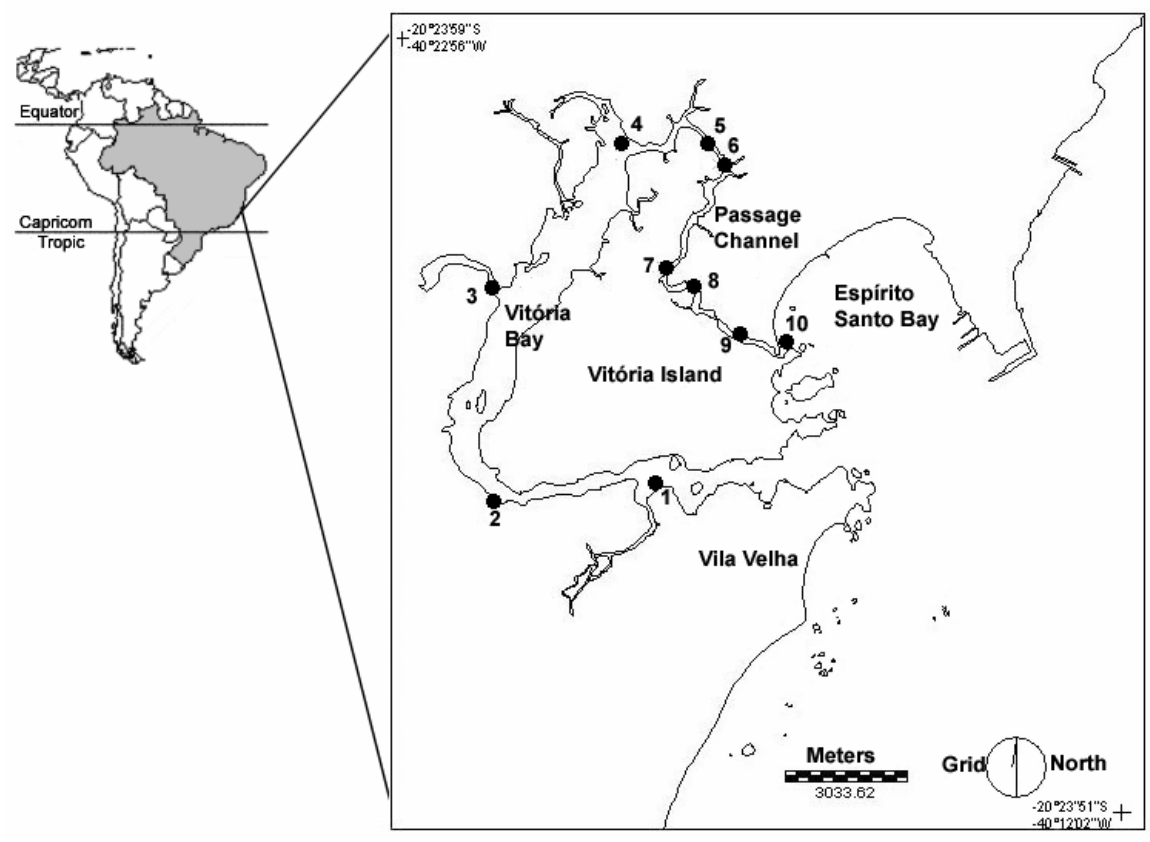

Fig. 1. Map showing the location of ten sampling stations in the Vitória Bay/Passage Channel estuarine system. 


\section{Seasonal Sampling and Data Analysis}

Sampling of the biological material and environmental parameters was done every three months at ten stations from July 1997 (winter) to April 1998 (fall). No sample was taken at station 2 in July. Zooplankton samples were collected using a cylindrical-conical plankton net with a 30 -centimeter mouth opening and $200 \mu \mathrm{m}$ mesh, fitted with a mechanical flowmeter to estimate the amount of water filtered (Omori \& Ikeda, 1992). Sub-surface samples were obtained with tows at approximately 1 knot during five-minute periods. The biological material collected was preserved in an aqueous solution of formaldehyde $5 \%$, buffered with sodium tetra-borate. Along with the biological parameters, environmental parameters such as salinity and temperature were measured "in situ" at each sampling station throughout the water column using portable multi-sound equipment (YSI 85). Salinity is expressed in practical salinity units (psu). A total of 39 samples were collected during the sampling period.

Aliquots were taken with a Folsom Plankton splitter and chaetognaths were sorted out of the aliquots, counted under a Leica GZ6 stereoscopic microscope and identified in accordance with the relevant literature (Boltovskoy, 1981; Casanova, 1999; Pierrot-Bults, 1996; Pierrot-Bults \& Chidgey, 1988). Copepod abundance was also estimated in each sample for further correlation with chaetognaths. Numbers of organisms were expressed as individuals per cubic meter of filtered seawater.

Multivariate analysis of the environmental variables and copepod abundance related to chaetognath abundance and distribution was performed using the Spearman correlation $(p<0.05)$. Group analysis was also made to evaluate the distribution by species.

\section{RESUlts}

Over the study period, water temperature varied between 22.0 and $28.8^{\circ} \mathrm{C}$, with higher values during summer and fall at the sampling sites in the inner part of the Passage Channel (Fig. 2). Salinity varied between 12 and 38 psu with the highest values occurring during fall and spring, mainly at the sampling stations in the outer estuary region (Fig. 3).

Five species of chaetognaths were identified in the Vitória Bay estuarine system: Sagitta decipiens Fowler, 1905, Sagitta enflata Grassi, 1881, Sagitta friderici Ritter-Záhony, 1910, Sagitta hispida Conant, 1895 and Sagitta minima Grassi, 1881.

During winter, $S$. friderici was the dominant species at the outer stations with approximately 36 ind. $\mathrm{m}^{-3}$. The same species was also found right in the middle of the estuary (Fig. 4), where salinities were around 14 psu (Fig. 3). S. enflata and S. decipiens were found in one of the estuary entrances where salinity was higher, the former being the more abundant (36.5 ind. $\mathrm{m}^{-3}$ ) in this area (Fig. 4). $S$. decipiens was the second species observed in the areas with greater freshwater input in the inner part of the estuary, along with $S$. friderici, both with reduced abundance (2.4 ind. $\mathrm{m}^{-3}$ each) (Fig. 4).

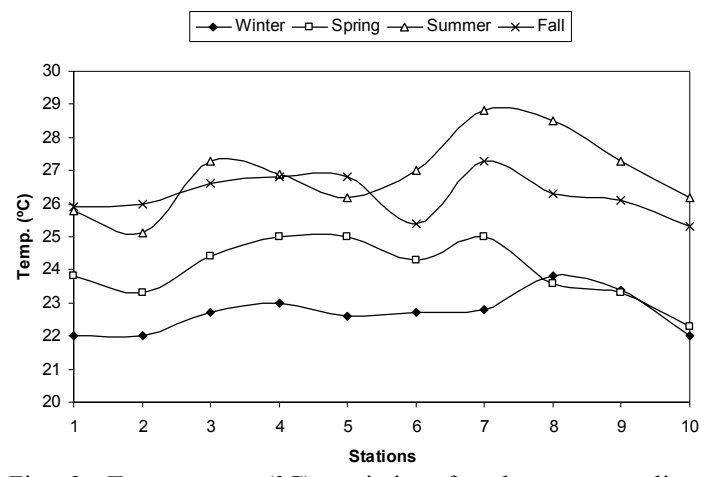

Fig. 2. Temperature $\left({ }^{\circ} \mathrm{C}\right)$ variation for the ten sampling stations between July 1997 and April 1998 in the Vitória Bay estuarine system.

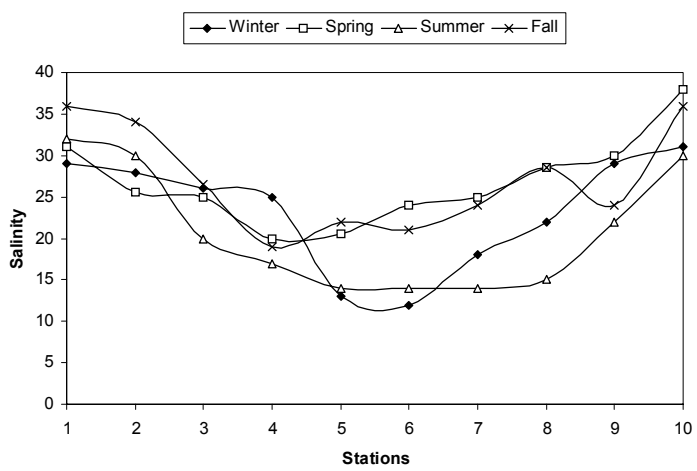

Fig. 3. Salinity (psu) variation for the ten sampling stations between July 1997 and April 1998 in the Vitória Bay estuarine system.

In spring, chaetognaths were also abundant in the outer region of the estuary (Fig. 5). The most abundant species for this season was $S$. enflata, attaining almost 40 ind. ${ }^{-3}$ (Fig. 5) where salinity values reached their peak in the sampling period (37.5 psu - Fig. 3). Other abundant species were $S$. friderici and $S$. decipiens. $S$. minima had its first and only occurrence $\left(0.4\right.$ ind. $\mathrm{m}^{-3}$ at St. 2$)$ in the estuary during the entire sampling period. However, hardly any chaetognaths were present in the estuary in the summer. In this period, $S$. friderici was found only in the outer estuary, though in small numbers (max. of 1.9 ind. $\mathrm{m}^{-3}$ ) (Fig. 6).

In contrast, chaetognaths showed a slight increase in abundance in the fall as compared to the 
summer. Sagitta friderici was the most numerons species in the system, but with no more than 10.2 ind. $\mathrm{m}^{-3}$ at the entrance to Vitória Bay. Sagitta friderici was the only chaetognath species found right in the middle of the Passage Channel (Fig. 7), with salinities around 23 (Fig. 3). Other species present during the fall were $S$. enflata, $S$. decipiens and $S$. hispida, with this last occurring, on the first and only occasion, at station 2 , though in small numbers $(0.4$ ind. $\mathrm{m}^{-3}-$ Fig. 7).

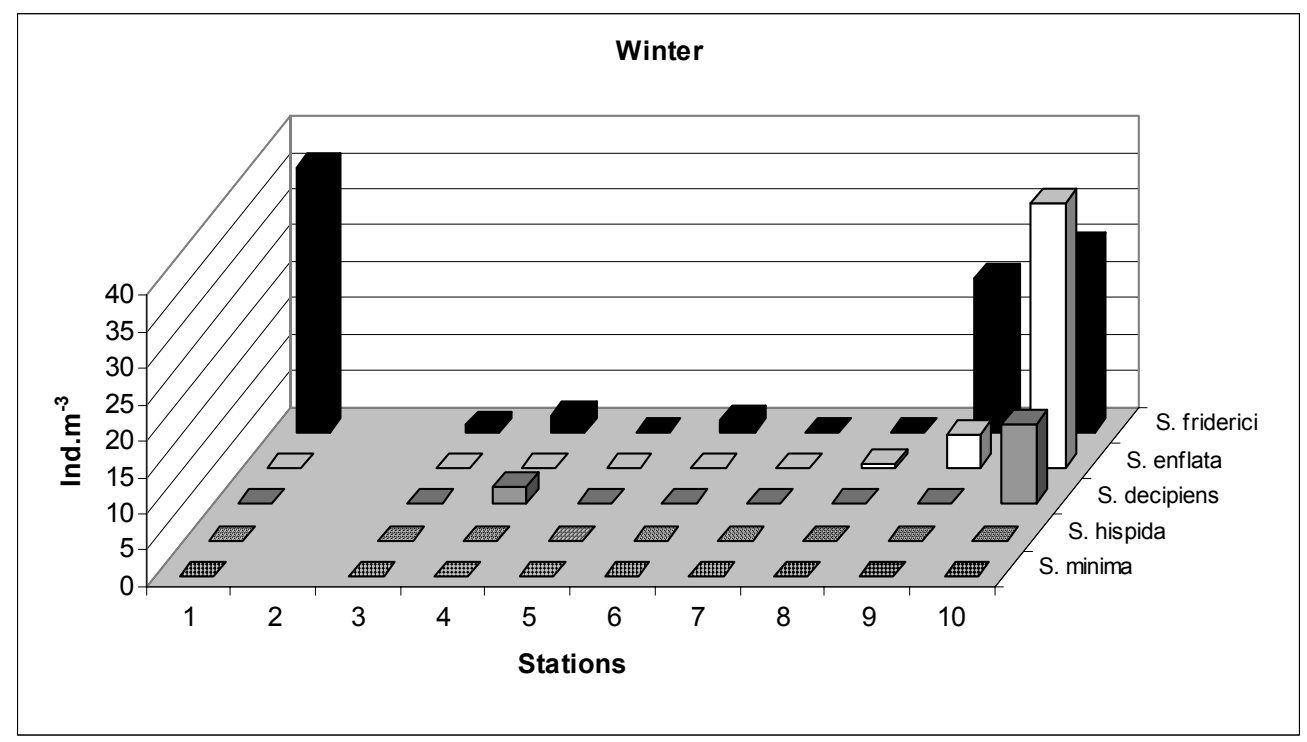

Fig. 4. Winter distribution of chaetognaths in the Vitória Bay/Passage Channel estuarine system (ind. $\mathrm{m}^{-3}$ ).

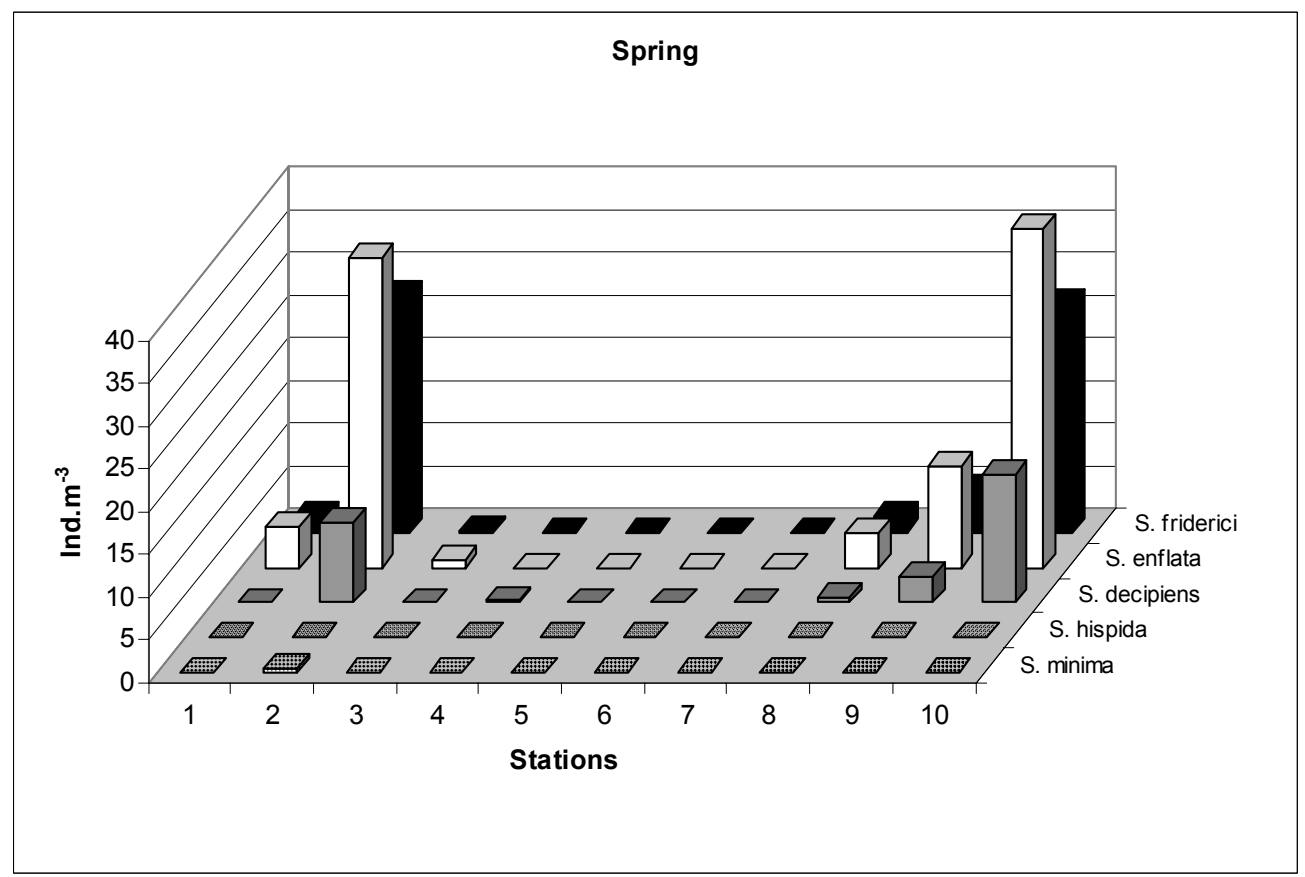

Fig. 5. Spring distribution of chaetognaths in the Vitória Bay/Passage Channel estuarine system (ind. $\mathrm{m}^{-3}$ ). 


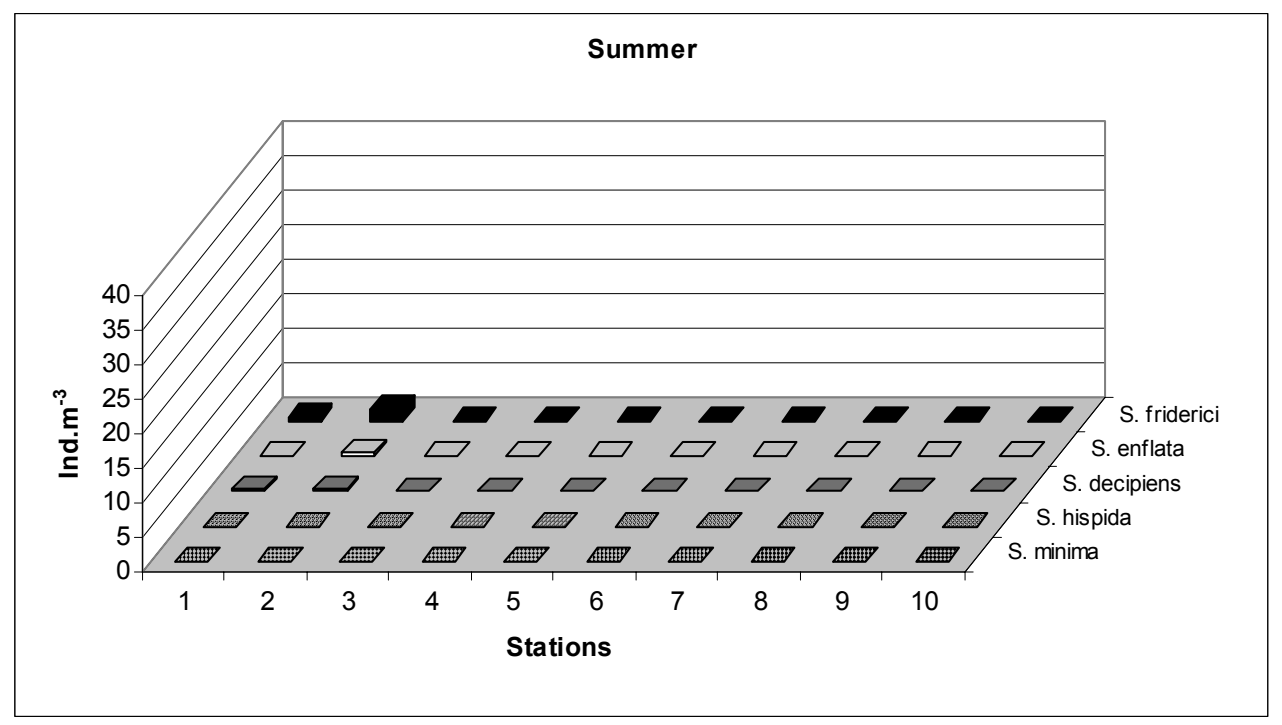

Fig. 6. Summer distribution of chaetognaths in the Vitória Bay/Passage Channel estuarine system (ind. $\mathrm{m}^{-3}$ )

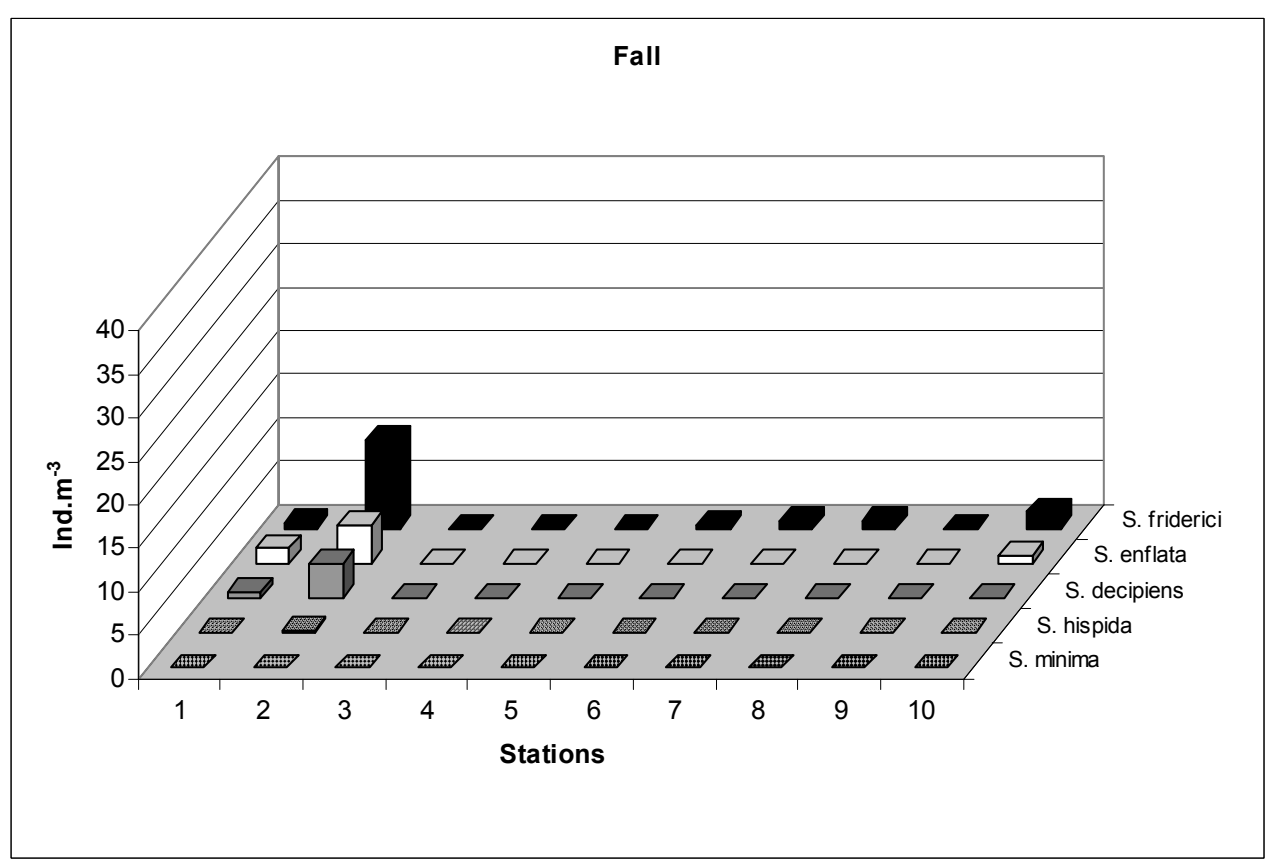

Fig. 7. Fall distribution of chaetognaths in the Vitória Bay/Passage Channel estuarine system (ind. $\mathrm{m}^{-3}$ ).

Table 1 shows the correlation values obtained by the Spearman test between temperature, salinity and copepod abundance and the chaetognath species. Copepod data were obtained elsewhere. $S$. enflata had a positive correlation with salinity and a tendency to negative correlation with temperature. This same pattern was observed for $S$. friderici and $S$. decipiens, whereas $S$. hispida and S. minima did not show any significant correlation with either temperature or salinity. On the other hand, positive 
correlation was observed between copepod abundance and S. enflata, S. friderici and S. decipiens.

Table 1. Spearman correlation among the environmental variables, copepod abundance and chaetognath abundance in the Vitória Bay/Passage Channel estuarine system.

\begin{tabular}{cccc}
\hline \hline $\begin{array}{c}\text { Chaetognath } \\
\text { Species }\end{array}$ & Temperature & Salinity & $\begin{array}{c}\text { Copepod } \\
\text { Abundance }\end{array}$ \\
\hline Sagitta enflata & -0.39 & 0.64 & 0.43 \\
Sagitta friderici & -0.51 & 0.66 & 0.48 \\
Sagitta decipiens & -0.33 & 0.54 & 0.42 \\
Sagitta minina & -0.13 & 0.03 & 0.21 \\
Sagitta hispida & 0.07 & 0.22 & 0.10 \\
\hline
\end{tabular}

Cluster analysis (r-mode) for the chaetognath species revealed the existence of two groups: group A consisting of $S$. hispida, S. minima and $S$. decipiens, and group B of $S$. friderici and $S$. enflata (Fig. 8).

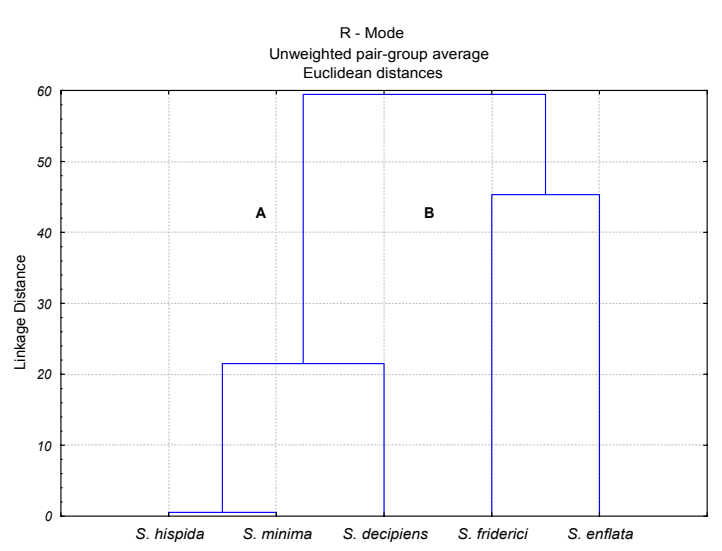

Fig. 8. Cluster analysis of chaetognath species in the Vitória Bay/Passage Channel estuarine system.

\section{Discussion}

The results obtained in this study show that most of the species present in the Vitória Bay/Passage Channel estuarine system, such as $S$. hispida, $S$. enflata, $S$. decipiens and $S$. minima, are typical inhabitants of coastal and oceanic waters (Casanova, 1999). The higher abundance observed during winter and spring are in accordance with other studies of Brazilian coastal regions (Liang \& Vega-Pérez, 1994).

The first evidence of $S$. friderici in Espírito Santo Bay, adjacent to Vitória Bay, State of Espírito Santo, was recorded by Bonecker et al. (1987). In the present study, $S$. friderici was one of the most abundant chaetognath species in the Vitória Bay/Passage Channel estuarine system during the entire year. The occurrence of this species has also been observed in other Brazilian estuarine systems (Montú, 1980; Lansac Tôha \& Lima, 1993 and Lopes, 1996). According to Casanova (1999), S. friderici is a typical neritic species and can be found off the South American coast, this raising the possibility of its being found in many coastal systems. S. friderici is also considered an indicator of colder waters and regions with upwelling (Liang \& Vega-Pérez, 2001). In the present study, $S$. friderici and $S$. decipiens were found in the middle of the estuary, where salinities were around 14 during the wet season and near an unusually low 12 psu during the dry season.

The results obtained in the present study show that the chaetognath species found in the Vitoria Bay area only enter this estuarine system due to the tidal effect, not being typical residents. This was to be expected especially because this group mainly inhabits coastal and oceanic regions (Casanova, 1999). The presence of $S$. friderici in very low salinities might be explained either by a higher tolerance of this organism to lower salinities or just as a result of the fact that few individuals were trapped in the estuary when the tide started to ebb. Sagitta enflata, a cosmopolitan species found in regions where salinities can vary frequently and markedly (Boltovskoy, 1981), has also already been recorded in Brazilian estuaries (Montú, 1980; Lira \& Magalhães, 1996: Lopes, 1996). In this study, $S$. enflata was abundant throughout the year at the stations closer to the entrance of the Bay and Channel, where the salinity was higher. Liang \& Vega-Pérez (2001) found low densities of S. enflata in the coastal region off Vitória, and observed that this species seemed to be limited to the areas of high salinity values $(>36)$ found in the tropical waters of the region, since this is a semi-neritic species (Liang \& VegaPérez, 2002).

Sagitta hispida, a tropical species whose distribution extends southward with the Brazil Current (Casanova, 1999), is mainly neritic and is distributed in both oceanic and coastal waters (Alvariño, 1965). $S$. hispida has not so far been recorded in estuarine waters in Brazil. However, in this study, a low abundance of $S$. hispida was observed in one sampling station in the Vitória Bay area, probably carried in by a strong tidal current. This species is known to be able to survive in salinities varying from 20 to 45 (Boltovskoy, 1981).

Sagitta minima is a neritic species found in both coastal and oceanic areas (Alvariño, 1965). It has never before been recorded in Brazilian estuaries, this being its first recorded occurrence in this type of system, as also for the State of Espírito Santo. Some authors limit the occurrence of this species to tropicalsubtropical waters (Casanova, 1999). The results obtained in this study indicate that $S$. minima is associated with high temperatures $\left(26.0^{\circ} \mathrm{C}\right)$, during the fall. The same is true for S. decipiens, another oceanic 
and costal species distributed from the equator down to $40^{\circ} \mathrm{S}$, occurring mainly in subtropical waters (Casanova, 1999).

Liang \& Vega-Pérez (1994) mentioned that the distribution and occurrence of chaetognaths are determined by hydrological conditions. In this study, the distribution of the two dominant species $S$. friderici and $S$. enflata was associated with the sampling stations characterized by their elevated salinity values, as can be observed from the Spearman correlation test results (Table 1), indicating the entrance of coastal waters into the estuary.

The occurrence of S. enflata e S. friderici throughout the year, along with the other species observed in the study area, is likely to be due to the tidal currents that entered the estuary during the sampling period, and were trapped in this system.

Apart from hydrological conditions, food availability also seems to influence chaetognath distribution. Copepods are important food items for chaetognaths (Liang \& Vega-Pérez, 1995). PierrotBults (1996) mentioned that approximately 10 to $30 \%$ of the copepod biomass is transferred to the chaetognath biomass. The results obtained in this study are in accordance with those observations, since a close correlation of chaetognath occurrence and high copepod densities was observed.

\section{ACKNOWLEDGMENTS}

We would like to thank CNPq (Brazil's Scientific and Technological Development Council), FACITEC (Vitória City Hall Science and Technology Support Fund) for the financial support for this research.

\section{REFERENCES}

Almeida-Prado, M. S. 1968. Distribution and annual occurrence of Chaetognatha off Cananéia and Santos coast (São Paulo, Brazil). Bolm Inst. oceanogr., S Paulo, 17(1):33-55

Alvariño, A. 1965. Chaetognaths. Oceanogr. mar. Biol. a. Rev., 3:115-194.

Boltovskoy, D. ed. 1981. Atlas del zooplancton del Atlántico Sudoccidental. Mar del Plata, Argentina, INIDEP. 936p.

Bonecker, S. L. C.; Bonecker, A. C. T.; Rivera Tenenbaum, D.; Bassani Bastos, C. T.; Nogueira, C. R.; Santos, L. H. S.; Reis, J. M. L. Dos; Dias, C. de O.; Reynier, M. V.; Dias, A. de S. \& Coelho, M. J. 1987. Distribuição espaço-temporal das comunidades planctônicas na Baía do Espírito Santo (Brasil). In: CONGRESSO LATINOAMERICANO SOBRE CIÊNCIAS DEL MAR. 2. Chile, 1987. Anais. Lima, Alicmar, 1987. p. 159-179.
Casanova, J. P. 1999. Chaetognatha. In: Boltovskoy, D. ed. South Atlantic Zooplankton. Leiden, The Netherland, Backhuys Publishers. p. 1353-1374.

Lansac Tôha, F. A. \& Lima, A. F. 1993. Ecologia do zooplâncton do Estuário do Rio Una do Prelado (São Paulo, Brasil). Acta Limnol. Brasiliensia, (6): 82-95.

Liang, T. H. \& Vega-Pérez, L. A. 1994. Studies on chaetognaths off Ubatuba region, Brazil. I. Distribution and abundance. Bolm Inst. oceanogr., S Paulo, 42 (1/2):73-84.

Liang, T. H. \& Vega-Pérez, L. A. 1995. Studies on chaetognaths off Ubatuba region, Brazil. II. Feeding habits. Bolm Inst. oceanogr., S Paulo, 43(1):27-40.

Liang, T. H. \& Vega-Pérez, L. A. 2001. Diversity, abundance and biomass of epiplanktonic chaetognath off South Atlantic western sector, from Cabo Frio $\left(23^{\circ} \mathrm{S}, 42^{\circ} \mathrm{W}\right)$ to São Pedro and São Paulo Rocks $\left(01^{\circ} \mathrm{N}, 29^{\circ} \mathrm{W}\right)$. Oceanides, 16(1):34-48.

Liang, T. H. \& Vega-Pérez, L. A. 2002. Distribution, abundance and biomass of Chaetognaths off São Sebastião region, Brazil in February 1994. Rev. bras. Oceanogr., 50(único):1-12.

Lira, M. C. de A. \& Magalhães, E. M. de M. 1996. Composição do zooplâncton do Complexo EstuarinoLagunar Mundaú/Manguaba (Alagoas-Brasil). Bolm Est. Cienc. Mar., 9:31-45.

Lopes, R. M. 1996. Hydrography and Zooplankton Community Structure: A comparative study among estuaries of the Juréia-Itatins Ecological Station (Southeastern Brazil). Nerítica, 10:27-40.

Montú, M. 1980. Zooplâncton do estuário da Lagoa dos Patos. I. Estrutura e variações temporais e espaciais da comunidade. Atlântica, 4:53-72.

Omori, M. \& Ikeda, T. 1992. Methods in marine zooplankton ecology. Florida, Krieger. 332p.

Paranaguá, M. N. \& Nascimento-Vieira, D. A. 1984. Estudo Ecológico da Região de Itamaracá, Pernambuco-Brasil. XXV. Zooplâncton do Rio Botafogo. Trabhs. Oceanogr., Univ. Fed. Pernambuco, 18:193-206.

Pierrot-Bults, A. C. 1996. XIV. Chaetognatha. In: Gasca, R. \& Suárez, E., eds. Introducción al estudio del zooplancton marino. México, ECOSUR/CONACYT. p.529-596.

Pierrot-Bults, A. C. \& Chidgey, K. C. 1988. Chaetognatha. In: Kermack, D. M. \& Barner, R. S. K. eds. Synopsis of the British Fauna (New Series), $n^{\circ}$ 39. Linn. Soc. London, Leiden, 66p.

Vega-Pérez, L. A. \& Liang, T. H. 1992. Feeding of a pelagic chaetognath, Sagitta friderici Ritter-Záhony off Ubatuba region (São Paulo, Brazil). Bolm Inst. oceanogr., S Paulo, 40(1/2):93-100.

(Manuscript received 02 March 2005; revised 04 May 2005; accepted 12 August 2005) 